\title{
Molecular cytogenetics of valuable Arctic and sub-Arctic pasture grass species from the Aveneae/Poeae tribe complex (Poaceae)
}

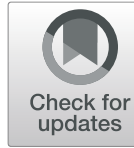

\author{
Alexandra V. Amosova ${ }^{1 * \dagger} \mathbb{D}$, Svyatoslav A. Zoshchuk ${ }^{1 \dagger}$, Alexander V. Rodionov², Lilit Ghukasyan', \\ Tatiana E. Samatadze', Elizaveta O. Punina ${ }^{2}$, Igor G. Loskutov ${ }^{3}$, Olga Yu. Yurkevich ${ }^{1}$ and Olga V. Muravenko ${ }^{1}$
}

\begin{abstract}
Background: Grasslands in the Arctic tundra undergo irreversible degradation due to climatic changes and also over-exploitation and depletion of scarce resources. Comprehensive investigations of cytogenomic structures of valuable Arctic and sub-Arctic grassland species is essential for clarifying their genetic peculiarities and phylogenetic relationships, and also successful developing new forage grass cultivars with high levels of adaptation, stable productivity and longevity. We performed molecular cytogenetic characterization of insufficiently studied pasture grass species (Poaceae) from related genera representing two neighboring clades: 1) Deschampsia and Holcus; 2) Alopecurus, Arctagrostis and Beckmannia, which are the primary fodder resources in the Arctic tundra.
\end{abstract}

Results: We constructed the integrated schematic maps of distribution of these species in the northern, central and eastern parts of Eurasia based on the currently available data as only scattered data on their occurrence is currently available. The species karyotypes were examined with the use of DAPI-banding, multicolour FISH with 35S rDNA, 5S rDNA and the $(\mathrm{GTT})_{9}$ microsatellite motif and also sequential rapid multocolour GISH with genomic DNAs of Deschampsia sukatschewii, Deschampsia flexuosa and Holcus lanatus belonging to one of the studied clades. Cytogenomic structures of the species were specified; peculiarities and common features of their genomes were revealed. Different chromosomal rearrangements were detected in Beckmannia syzigachne, Deschampsia cespitosa and D. flexuosa; B chromosomes with distinct DAPI-bands were observed in karyotypes of D. cespitosa and H. lanatus.

Conclusions: The peculiarities of distribution patterns of the examined chromosomal markers and also presence of common homologous DNA repeats in karyotypes of the studies species allowed us to verify their relationships. The obtained unique data on distribution areas and cytogenomic structures of the valuable Arctic and sub-Arctic pasture species are important for further genetic and biotechnological studies and also plant breeding progress.

\section{Background}

According to current molecular phylogenetic studies, the tribe Poeae R. Br. (Pooideae, Poaceae) now includes the formerly separate tribe Aveneae Dum [1, 2]. The Aveneae/Poeae tribe complex comprises a large number of crops and forage plants which play an important role for humans and animals. As an example, economically important oat is the most ancient food supplies for humankind [3]. Lots of members of the Aveneae/Poeae

\footnotetext{
* Correspondence: amomar@mail.ru

${ }^{\dagger}$ Alexandra V. Amosova and Svyatoslav A. Zoshchuk contributed equally to this work.

${ }^{1}$ Engelhardt Institute of Molecular Biology, Russian Academy of Sciences, Moscow, Russian Federation

Full list of author information is available at the end of the article
}

tribe are polymorphic species with a wide geographical distribution, high morphological diversity and complicated taxonomy [1, 2, 4, 5]. Species of this tribe are highly tolerant to stressful and variable environmental conditions including extreme Arctic and Antarctic habitats [6-8]. In particular, Deschampsia antarctica E. Desv. is the only one species within the Poaceae family adapted to the harshest Antarctic environment [7]. Polar and subpolar ecotypes of perennial cereals from the related genera Alopecurus, Arctagrostis, Beckmannia, Deschampsia and Holcus are characterized by high biological value, stable productivity and longevity and used as native and/or introduced forage resources in the Arctic tundra $[6,7,9-12]$. Animal husbandry has always

(c) The Author(s). 2019 Open Access This article is distributed under the terms of the Creative Commons Attribution 4.0 International License (http://creativecommons.org/licenses/by/4.0/), which permits unrestricted use, distribution, and reproduction in any medium, provided you give appropriate credit to the original author(s) and the source, provide a link to the Creative Commons license, and indicate if changes were made. The Creative Commons Public Domain Dedication waiver (http://creativecommons.org/publicdomain/zero/1.0/) applies to the data made available in this article, unless otherwise stated. 
been the principal economic activities of the northern indigenous peoples (the Yakuts, Nenets, Evenki, etc.), and pasture grasses are the primary fodder resources in the Arctic tundra [10]. Currently, the unique Arctic ecosystem requires special attention as grasslands in the Arctic regions undergo irreversible degradation due to climatic changes and also over-exploitation and depletion of scarce resources [10]. Sustainable grazing strategies can have a significant impact on rehabilitating the degraded grasslands. Also, introduction of native Arctic grassland species and also non-native cold-hardy ecotypes of perennial grasses with high levels of adaptation and seed productivity as well as development of new valuable cultivars from promising wild morphotypes could be the strategies for reducing feed costs and increasing feed efficiency in the Arctic and sub-Arctic regions $[11,12]$. Moreover, the investigation of the evolutionary changes occurred in their genomes (especially, under environmental stress factors) is an important aspect for clarifying the mechanisms related to abiotic stress tolerance and for further crop breeding strategies $[13,14]$.

Despite widespread occurrence and economic value of most cereals from the Aveneae/Poeae tribe, their genomes still remain insufficiently studied [14, 15]. Due to the agricultural significance, oat species have become the subject of complex investigation, and extensive molecular studies have largely clarified diversity and evolution of the genus Avena [16-20]. Phylogenetic studies in recent decades, mostly based on analyses of different DNA sequences from both plastid regions and nuclear ribosomal regions, have helped to clarify the evolutionary relationships within the Aveneae/Poeae complex [4, 5, 15, 21-23]. However, the details of the phylogeny among many genera and suprageneric taxa of this diverse grass tribe still remain controversial [23]. Furthermore, the complicated breeding system, that is peculiar to evolution of major cereals from this tribe, included interspecific and intergeneric hybridization which was accompanied by the allopolyploid formation [24]. Moreover, environmental stress factors can lead to physiological stress followed by structural variations (chromosome rearrangements, mixoploidy and aneuploidy) in plant genomes [25-27]. Therefore, the investigation of genomes of such species should comprise their molecular cytogenetic characterization [15, 23]. Particularly, physical mapping of specific DNA probes to individual chromosomes is a promising tool for analysis of chromosome organization and evolutionary processes in plant genomes [15]. Knowledge of the chromosome localization of repetitive DNA families is very useful in the assembly of genome sequences and their assignment to physical chromosomes [28].
Currently, detailed cytogenetic information is available for less than half of the altogether 60-70 genera of the Aveneae/Poeae [15, 29], and among them, the genus Avena is the most extensively studied with the use of FISH with different sat DNAs and staining of constitutive heterochromatin regions on chromosomes [30-34]. Molecular phylogenetic and cytogenetic studies indicated that diploid Avena species carried different types of the A genome (As; $\mathrm{Al}$; Ac; $\mathrm{Ad}$ and $\mathrm{Ap}$ ) or $\mathrm{C}$ genome ( $\mathrm{Cv}$ and $\mathrm{Cp}$ ); tetraploid Avena species $(2 \mathrm{n}=4 \mathrm{x}=28)$ comprised $\mathrm{AB}$ or $\mathrm{AC}$ genomes; and hexaploid species $(2 \mathrm{n}=6 \mathrm{x}=42)$ had ACD genomes [16-20,30-32]. Also, it was assumed that $\mathrm{Al}$ genome was the most ancient oat genome which could be a possible progenitor of $\mathrm{B}$ and $\mathrm{D}$ genomes of the genus Avena [16-20, 30-32, 35]. Besides, molecular cytogenetic data were reported for several taxa of the Aveneae/Poeae genera including genera Arrhenatherum, Deschampsia, Helictotrichon, Pseudarrhenatherum, Trisetum and some others. Particularly, for D. cespitosa (L.) P. Beauv., a chromosome number $2 \mathrm{n}=26=2(6 \mathrm{~m}+4 \mathrm{sm}+3 \mathrm{st})$ with three pairs of satellite chromosomes was determined and also chromosomal distribution of rDNA sites and $\mathrm{CON} /$ COM DNA repeats were described $[15,36]$. Recently, we have performed a comparative molecular cytogenetic analysis of several Deschampsia species sampled in different regions and environments including sub-Arctic mountain tundra (D. sukatschewii (Popl.) Roshev) [27, 37]. FISH with rDNA and rapid GISH with genomic DNA of closely related (D. antarctica E. Desv. and D. cespitosa) and also the most distant (D. flexuosa (L.) Trin. (=Avenella flexuosa (L.) Drejer) species of the genus have indicated variations in the karyotype structure and ploidy status as well as in distribution of the studied chromosomal markers, which could be related to plasticity of their genomes [27, 37].

Nevertheless, cytogenetic data on most members of the Aveneae/Poeae tribe still remain limited; in particular, karyotypes of many valuable pasture grass species important for Arctic and sub-Arctic regions (including Alopecurus aequalis Sobol. $(2 \mathrm{n}=14)$, Alopecurus arundinaceus Poir. $(2 \mathrm{n}=4 \mathrm{x}=28)$, Arctagrostis latifolia (R. Br.) Griseb. $(2 \mathrm{n}=4 \mathrm{x}=28)$, Beckmannia syzigachne (Steud.) Fernald. $(2 \mathrm{n}=14)$ and Holcus lanatus $\mathrm{L} .(2 \mathrm{n}=14))$ have been analysed by simple monochrome staining which resulted in the determination of chromosome number and ploidy level in these species [35, 38].

\section{Objectives}

In this study, we performed a molecular cytogenetic characterization of sub-Arctic accessions of $A$. aequalis, $A$. arundinaceus, $A$. latifolia, B. syzigachne, D. cespitosa, $D$. flexuosa and $H$. lanatus in order to specify their ploidy status and karyotypic features and also reveal possible structural chromosome rearrangements important for further crop breeding strategies. For a comparative 
assessment of cytogenetic peculiarities and karyogenomic similarities within the studied species, we also characterized an accession of Avena longiglumis Dur. containing the most ancient oat $\mathrm{Al}$ genome which also could be useful for development of new forage grass cultivars $[12,35,40]$.

\section{Methods}

\section{Plant materia}

Seeds of sub-Arctic tundra accessions of $A$. arundinaceus (144, Magadan region, RF: 59 $34^{\prime} \mathrm{N} ; 150^{\circ} 48^{\prime} \mathrm{E}$ ), $A$. latifolia (85, Magadan region, RF: $59^{\circ} 34^{\prime} \mathrm{N} ; 150^{\circ} 48^{\prime} \mathrm{E}$ ),

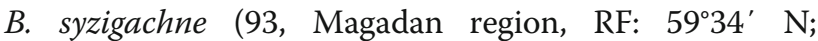
$150^{\circ} 48^{\prime}$ E), D. cespitosa (688, Vologda region, RF: 59 $9^{\circ} 13^{\prime}$ N; 39 $54^{\prime}$ E), D. flexuosa (598, Republic of Karelia, RF, $\left.63^{\circ} 49^{\prime} \mathrm{N} ; 33^{\circ} 00^{\prime} \mathrm{E}\right)$ and a Sub-Arctic mountain tundra accession of D. sukatschewii (78, Altai Mountains, 1400 $\mathrm{m}$ above mean sea level (mamsl), RF: 48 $45^{\prime} \mathrm{N} ; 8^{\circ} 36^{\prime}$ E) were received from the Laboratory of genetic resources of fodder plants, Federal Williams Research Center of Forage Production and Agroecology, Lobnya, Moscow region, RF. Seeds of A. longiglumis (k-1811, Morocco) were received from the Department of genetic resources of oat, rye and barley, FRC N.I. Vavilov AllRussian Institute of Plant Genetic Resources (VIR), St. Petersburg, RF. Sub-Arctic mountain tundra accessions of $A$. aequalis (Alt11-309, natural populations, Altai Mountains, 1200 mamsl, RF: $48^{\circ} 45^{\prime} \mathrm{N} ; 89^{\circ} 36^{\prime} \mathrm{E}$ ) and $H$. lanatus ( $\mathrm{T}-115$, natural populations, Caucasus Moun-

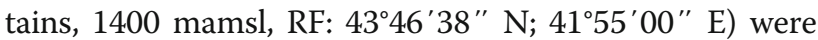
sampled and identified by Dr. E.O. Punina, Laboratory of Biosystematics and Cytology, Komarov Botanical Institute, RAS, St. Petersburg, RF. Collection of these wild plant samples and experimental research conducted on these materials were performed in accordance with the legal regulations of Komarov Botanical Institute, RAS, St. Petersburg, RF approved by the Ministry of Science and Higher Education of the Russian Federation.

\section{Chromosome spread preparation}

Mitotic chromosome spreads were prepared from plant root meristem according to the previously described technique [37].

\section{MC-FISH procedure}

Following probes were used for MC-FISH:

1. pTa71 containing a $9 \mathrm{~kb}$ long DNA sequence of common wheat including 18S-5.8S-26S (35S) rDNA [41]

2. pTa794 containing a $420 \mathrm{bp}$ long DNA sequence of wheat including 5S rDNA [42]
These DNA probes were labelled directly with SpectrumAqua and SpectrumRed fluorochromes (Abbott Molecular, Wiesbaden, Germany) by nick translation according to manufacturers' protocols.

3. The oligo-(GTT $)_{9}$ probe, labelled at the 3 '-end with fluorescein-12-dUTP (Roche diagnostics, Mannheim, Germany), was synthesized using a synthesizer ABI 394 (applied BioSystems, Redwood City, USA)

MC-FISH assays were performed with the use of a combination of these DNA probes as described previously [43]. After overnight hybridization, the slides were washed twice with $0.1 \mathrm{xSSC}$ at $44{ }^{\circ} \mathrm{C}$ for $10 \mathrm{~min}$, twice with $2 \times S S C$ at $44^{\circ} \mathrm{C}$ for $5 \mathrm{~min}$ followed by a 5 -min wash in $2 \mathrm{xSSC}$ and three washes in PBS for 3 min each at room temperature. Then the slides were dehydrated through a graded ethanol series and air dried. The oligo$(\mathrm{GTT})_{9}$ probe labelled with fluorescein was detected using anti-fluorescein/Oregon green, rabbit IgG fraction, Alexa Fluor 488 conjugate (Molecular Probes, Oregon, USA).

\section{DAPI staining}

After MC-FISH procedures, chromosome slides were stained with $0.1 \mu \mathrm{g} / \mathrm{ml}$ DAPI (4',6-diamidino-2-phenylindole) (Serva, Heidelberg, Germany) dissolved in Vectashield antifade mounting medium (Vector laboratories, Peterborough, UK).

\section{Rapid MC-GISH procedure}

Genomic DNAs of D. sukatschewii, H. lanatus and D. flexuosa were isolated from green leaves using $\mathrm{CTAB}$ (cetyltrimethylammonium bromide) standard protocol with minor modifications [44]. Then these genomic DNAs were labelled directly with SpectrumAqua or SpectrumRed (Abbott Molecular, Wiesbaden, Germany) by nick translation according to the manufacturer's instructions.

After the MC-FISH procedure and documentation of the hybridization patterns, a sequential rapid MC-GISH procedure was conducted on the same slide as described previously [27]. In rapid MC-GISH assays, labelled genomic DNAs of D. sukatschewii and $H$. lanatus (for $A$. aequalis, $A$. arundinaceus, $A$. latifolia, A. longiglumis, $B$. syzigachne, $D$. cespitosa and $D$. flexuosa) or $D$. flexuosa and D. sukatschewii (for H. lanatus) were used as DNA probes.

\section{Chromosome analysis}

The chromosome slides were examined with the use of an Olympus BX61 epifluorescence microscope (Olympus, Tokyo, Japan) equipped with a cooled high- 
resolution black and white CCD camera (Cool Snap, Roper Scientific Inc., Tucson, USA). Chromosome images were collected in grayscale channels and pseudocoloured. Then they were processed with Adobe Photoshop 10.0 (Adobe Systems Inc., Birmingham, USA) and VideoTesT-FISH 2.1 (IstaVideotest, St. Petersburg, Russia) software programs. In each species accession, five plants with fifteen metaphase plates were examined. In the karyotypes, the identification of chromosomes was performed based on their morphological similarities as well as revealed molecular cytogenetic markers. In the species karyograms of $A$. aequalis, $A$. arundinaceus, $A$. latifolia, A. longiglumis, B. syzigachne and $H$. lanatus, the chromosome pairs were set in the decreasing order of size. The cytological numerical designation of $D$. cespitosa and D. flexuosa was according to Amosova et al. [37].

\section{Results}

\section{Species distribution areas}

For A. aequalis, A. arundinaceus, A. latifolia, B. syzigachne, D. cespitosa, D. flexuosa, D. sukatschewii and $H$. lanatus, we constructed integrated schematic maps of their distribution in the northern, central and eastern parts of Eurasia based on the analysis of currently available data [2, 6, 45-52] (Fig. 1). In these regions, A. latifolia is distributed from the Arctic Archipelago of Svalbard to Chukotka Peninsula including the Archipelago of Novaya Zemlya $\left(75^{\circ} \mathrm{N}\right)$. Circumboreal-polar species, $A$. aequalis, $A$. arundinaceus and $D$. cespitosa are widespread in the Eurasian continent from the Arctic Scandinavia to the Far East regions and Chukotka Peninsula. Northern populations of $H$. lanatus and D. flexuosa occur in the Arctic Scandinavia and Kola Peninsula and also in Kamchatka Peninsula and Far East regions. B. syzigachne is widespread in the Eurasian continent from the Volga river basin to Chukotka Peninsula. D. sukatschewii is distributed in all northern regions of $\mathrm{Si}$ beria and Chukotka Peninsula (Fig. 1).

\section{Karyotype structure}

The accessions of the studied grass species presented diploid $2 \mathrm{n}=14$ (A. aequalis, A. longiglumis, B. syzigachne and $H$. lanatus) and also tetraploid $2 \mathrm{n}=28$ (A. arundinaceus, $A$. latifolia and $D$. flexuosa) karyotypes with the basic chromosome number $\mathrm{x}=7$ except for $D$. cespitosa having $2 n=26$ chromosomes. In several karyotypes of four $D$. cespitosa plants, one to three supernumerary small chromosomes with uncertain morphology were detected (Figs. 3e, f and 5). The number of these supernumerary chromosomes varied between the studied $D$. cespitosa plants as well as within the root meristem of each plant. In one karyotype of $H$. lanatus, a supernumerary chromosome was also revealed (Figs. 2i, j and 4).

Visual analysis showed that karyotypes of $A$. aequalis, $A$. longiglumis, $A$. arundinaceus, $A$. latifolia, B. syzigachne, $D$. flexuosa and $H$. lanatus contained metacentric and submetacentric chromosomes which were not very different in size and morphology (Figs. 2, 3, 4, and 5). In D. cespitosa karyotypes, metacentric, submetacentric and subtelocentric chromosomes were observed (Figs. 3e and 5).

\section{MC-FISH mapping of the (GTT), oligonucleotide, $35 \mathrm{~S}$ and 5S rDNA}

MC-FISH analysis revealed different patterns of chromosomal distributions of oligo-(GTT) $)_{9}$, 35S and 5S rDNA probes in karyotypes of the studied accessions summarized in Tables 1 and 2 (Supplementary information files).

In all examined karyotypes of the $A$. aequalis accession, MC-FISH analysis (performed for the first time) revealed large $35 \mathrm{~S}$ rDNA hybridization sites in the secondary constriction regions (short arms) of chromosome 6. Sites of $5 \mathrm{~S}$ rDNA were detected in the interstitial regions of chromosome pair 1 (long arms) and 4 (short arms). Small (GTT) ${ }_{9}$ sites were revealed in the subterminal regions of chromosome pair 2 (short arms) and 6 (long arms) (Figs. 2a and 4).

In all examined karyotypes of the A. longiglumis accession, 35S rDNA loci were reveled in the secondary constriction regions (short arms) of two chromosome pairs 1 and 6 . Sites of $5 \mathrm{~S}$ rDNA were detected in chromosome pair 6 (in the short arm adjacent to 35S rDNA loci and also in the proximal region of the long arm). The oligo$(\mathrm{GTT})_{9}$ probe produced signals on five chromosome pairs. Distinct signals were observed in the pericentromeric regions of chromosome pairs 2, 3 and 7. Besides, a number of minor sites were observed in chromosome pair 3 (in the interstitial and proximal regions of the short arms and in the subterminal region of the long arms) and chromosome pair 5 (along the long arms) (Figs. 2c and 4).

In all studied karyotypes of four plants of B. syzigachne, MC-FISH analysis (performed for the first time) revealed $35 \mathrm{~S}$ rDNA loci in the secondary constriction regions (short arms) of two chromosome pairs 2 and 3. 5S rDNA sites were observed in the subterminal region of the short arms and in the interstitial region of the long arms of chromosome pair1, and also in the distal region of the short arms of chromosome pair 2. Small $(\mathrm{GTT})_{9}$ sites were detected in the distal region of the short arms of chromosome pair 1 (Figs. 2e and 4).

In all studied karyotypes of one plant of the $B$. syzigachne accession, 35S rDNA loci were revealed in the secondary constriction regions (short arms) 


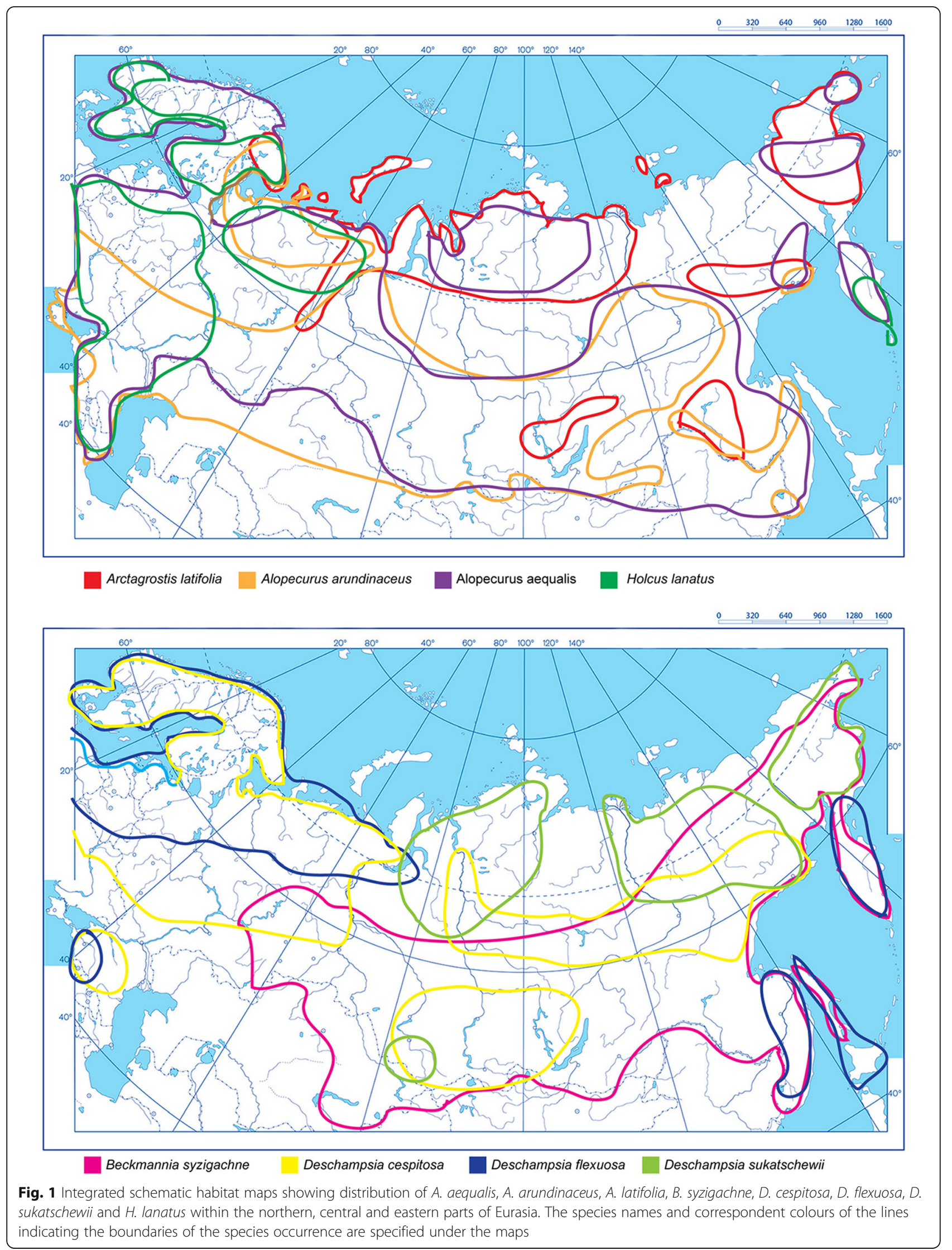



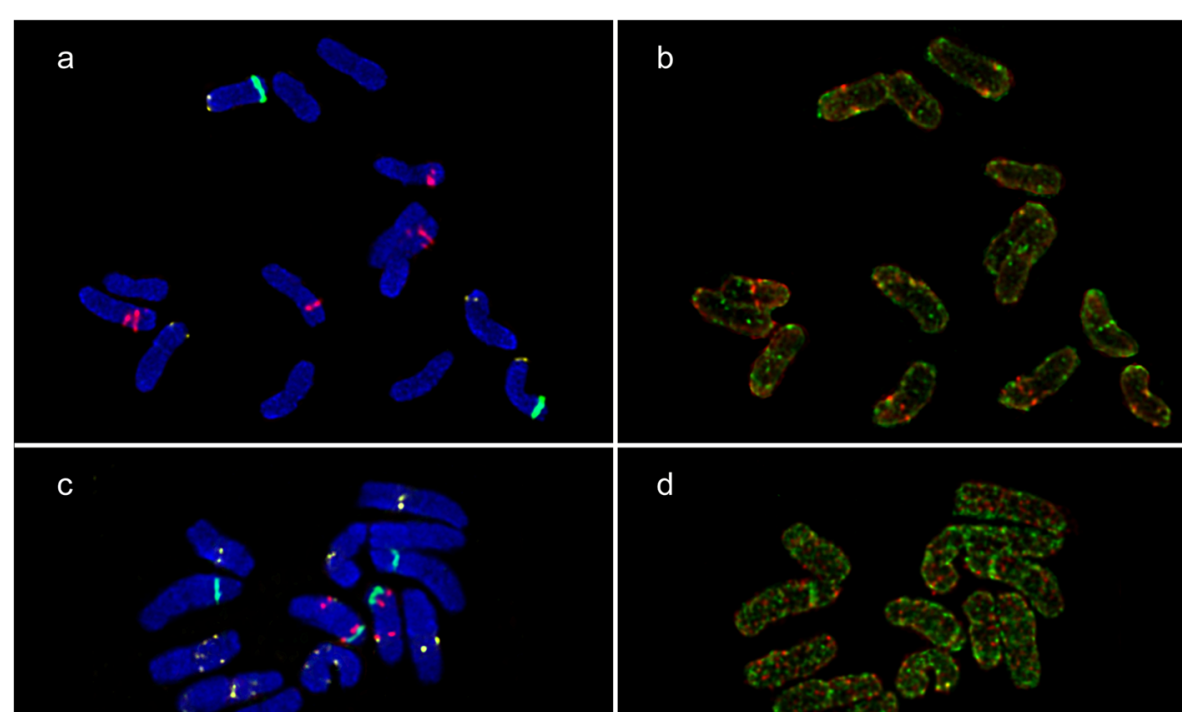

35 S rDNA
5 S rDNA

GTT

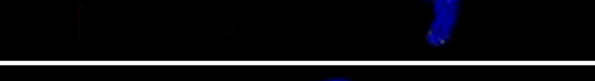

\section{f}

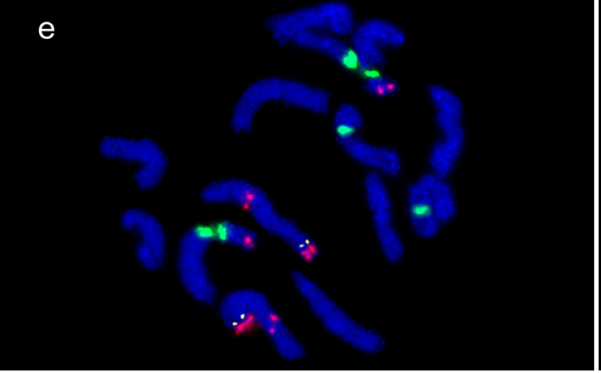

d

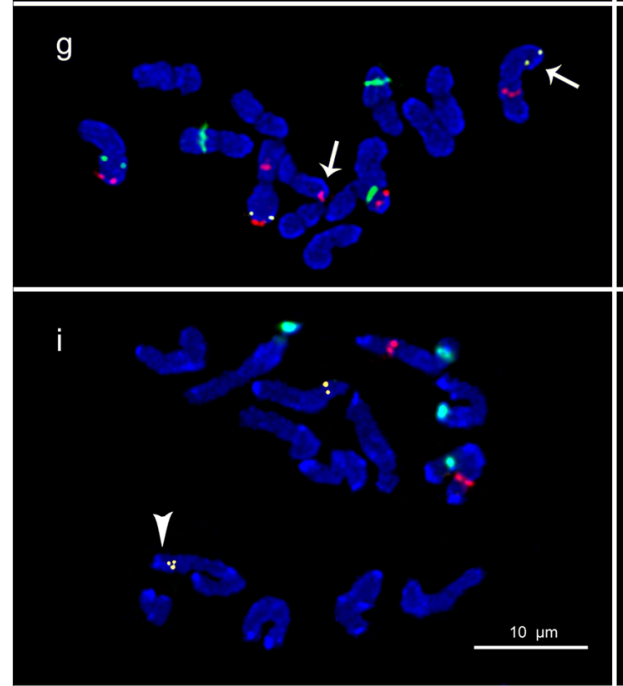

$\mathrm{h}$

h

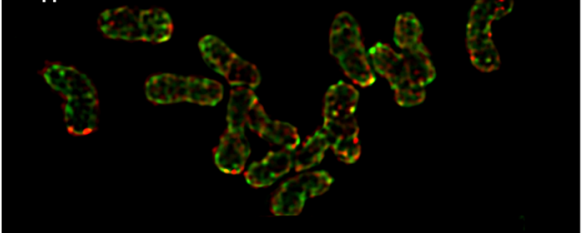

i

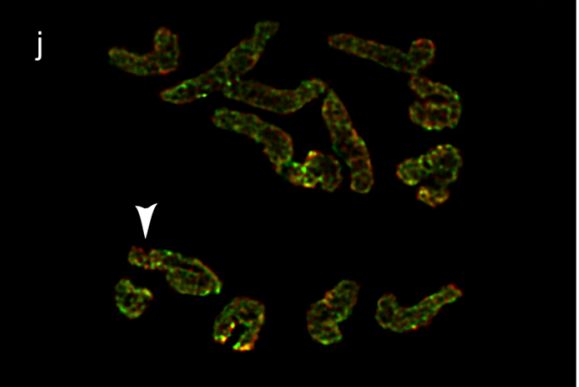

Fig. 2 Chromosome spreads of the studied diploid species. a, b A. aequalis, c, d A. longig/umis, e, f $B$. syzigachne (normal karyotype), $\mathbf{g}, \mathbf{h} B$. syzigachne (karyotype with a translocation $\mathrm{t}(\mathbf{1} ; 6))$ and $\mathbf{i}, \mathbf{j} \mathrm{H}$. lanatus. Merged fluorescent images after MC-FISH with $35 \mathrm{~S}$ rDNA (green), $5 \mathrm{~S}$ rDNA (red), oligo-(GTT) 9 (yellow) a, c, e, g and sequential rapid MC-GISH with genomic DNAs of $\mathbf{b}, \mathbf{d}, \mathbf{f} D$. sukatschewii (red) and $H$. lanatus (green) and also $\mathbf{h}$ D. sukatschewii (red) and D. flexuosa (green). DAPI chromosome staining - blue. Arrows point to chromosome rearrangements. Head of arrows point to a B chromosome. Scale bar - $10 \mu \mathrm{m}$ 


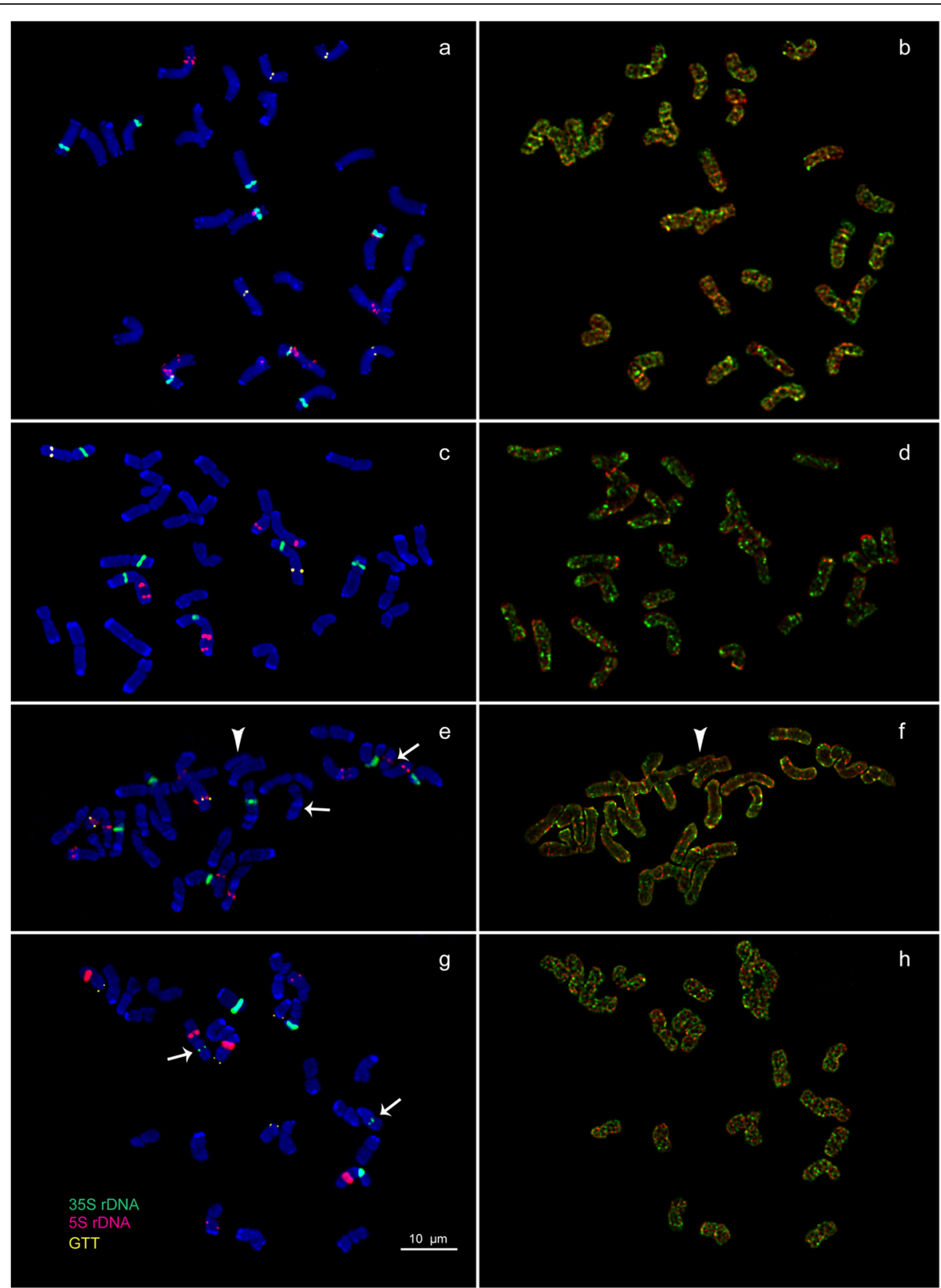

Fig. 3 Chromosome spreads of the studied polyploid species. a, b A. arundinaceus, $\mathbf{c}, \mathbf{d}$ A. latifolia, e, $\mathbf{f} D$. cespitosa and $\mathbf{g}, \mathbf{h} D$. flexuosa. Merged fluorescent images after MC-FISH with $35 \mathrm{~S}$ rDNA (green), $5 \mathrm{~S}$ rDNA (red), oligo-(GTT), (yellow) a, c, e, $\mathbf{g}$ and sequential rapid MC-GISH with genomic DNAs of D. sukatschewii (red) and H. lanatus (green) $\mathbf{b}, \mathbf{d}, \mathbf{f}, \mathbf{h}$. DAPI chromosome staining - blue. Arrows point to chromosome rearrangements. Head of arrows point to a B chromosome. Scale bar - $10 \mu \mathrm{m}$

of two chromosome pairs 2 and 3. 5S rDNA sites were observed in the subterminal region of the short arm (in the hemizygote state) and in the interstitial region of the long arms of chromosome pair 1, in the distal region of the short arms of chromosome pair 2 and in the distal region of the long arm (hemizygote state) of chromosome pair 6. Small $(\mathrm{GTT})_{9}$ sites were detected in the distal region of the short arms of chromosome pair 1 (Figs. $2 \mathrm{~g}$ and 4).
In all studied karyotypes of the $H$. lanatus accession, MC-FISH analysis (performed for the first time) revealed $35 \mathrm{~S}$ rDNA loci in the secondary constriction regions (short arms) of chromosome pairs 1 and 4 . Sites of $5 \mathrm{~S}$ rDNA were detected in the interstitial region of the long arms of chromosome pair 1. Small $(\mathrm{GTT})_{9}$ sites were observed in the distal region of the short arms of chromosome pair 3 (Figs. 2i and 4). 


\section{$\begin{array}{lllllllll}\text { Alopecurus aequalis } & 1 & 2 & 3 & 4 & 5 & 6 & 7\end{array}$ \\ inverted DAPI \\ 101111168181}

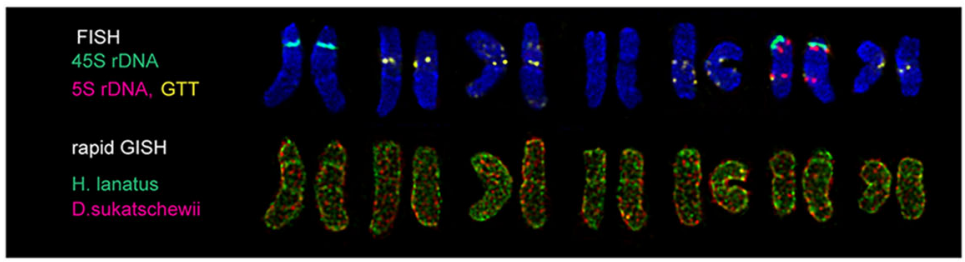

\begin{tabular}{llllllll} 
Avena longiglumis & 1 & 2 & 3 & 4 & 5 & 6 & 7 \\
\hline & &
\end{tabular}

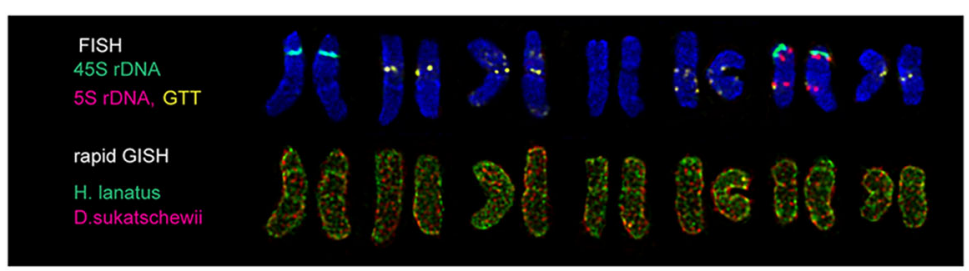

\begin{tabular}{llllllll} 
Beckmania syzigachne & 1 & 2 & 3 & 4 & 5 & 6 & 7 \\
\hline
\end{tabular}

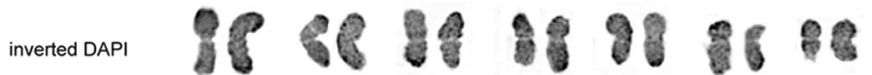

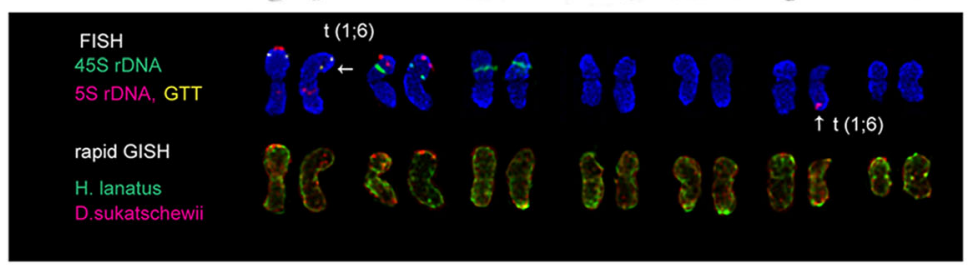

\begin{tabular}{lllllllll} 
Holcus lanatus & 1 & 2 & 3 & 4 & 5 & 6 & 7 & B \\
\hline
\end{tabular}

inverted DAPI 42 है

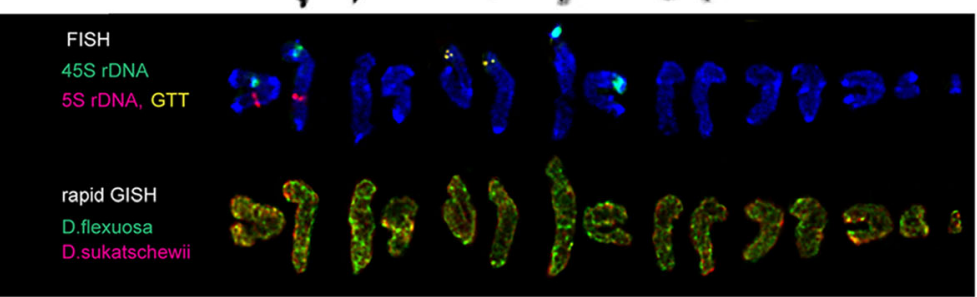

Fig. 4 Karyotypes of A. aequalis, A. longiglumis, B. syzigachne and H. lanatus. Karyograms of the metaphase plates shown in Fig. 2 after DAPIbanding (inverted images), MC-FISH with the oligo-(GTT), 35 S and 55 rDNA probes and also rapid MC-GISH with genomic DNAs of D. flexuosa, D. sukatschewii and H. lanatus. The correspondent probes and their pseudo-colours are specified in the left. Arrows point to chromosome rearrangements. B -B chromosome

In all examined karyotypes of the $A$. arundinaceus accession, MC-FISH analysis (performed for the first time) revealed large $35 \mathrm{~S}$ rDNA sites in the secondary constriction regions (short arms) of chromosome pairs 1, 3, 4 and 10. Sites of $5 \mathrm{~S}$ rDNA were visualized in the proximal region of the short (adjacent to the $35 \mathrm{~S}$ rDNA site) and long arms of chromosome pair 1, in the interstitial region of the long arms of chromosome pair 2 and in the short arms of chromosome pair 4 (adjacent to the 35S rDNA site). Distinct $(\mathrm{GTT})_{9}$ sites were detected in the 


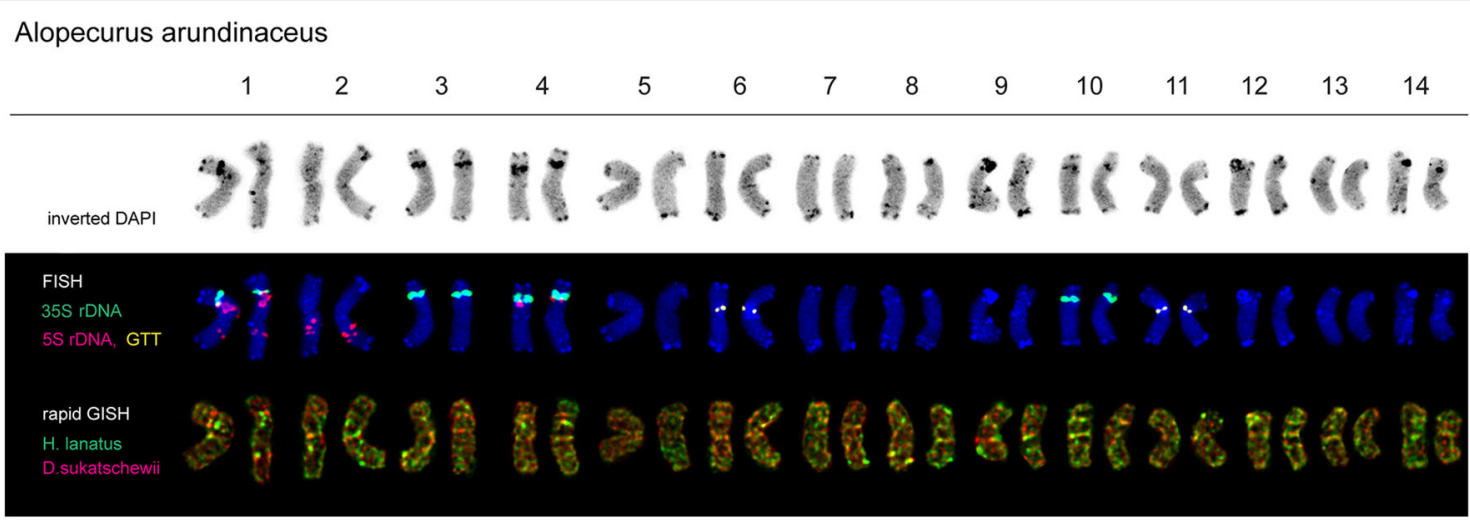

Arctagrostis latifolia

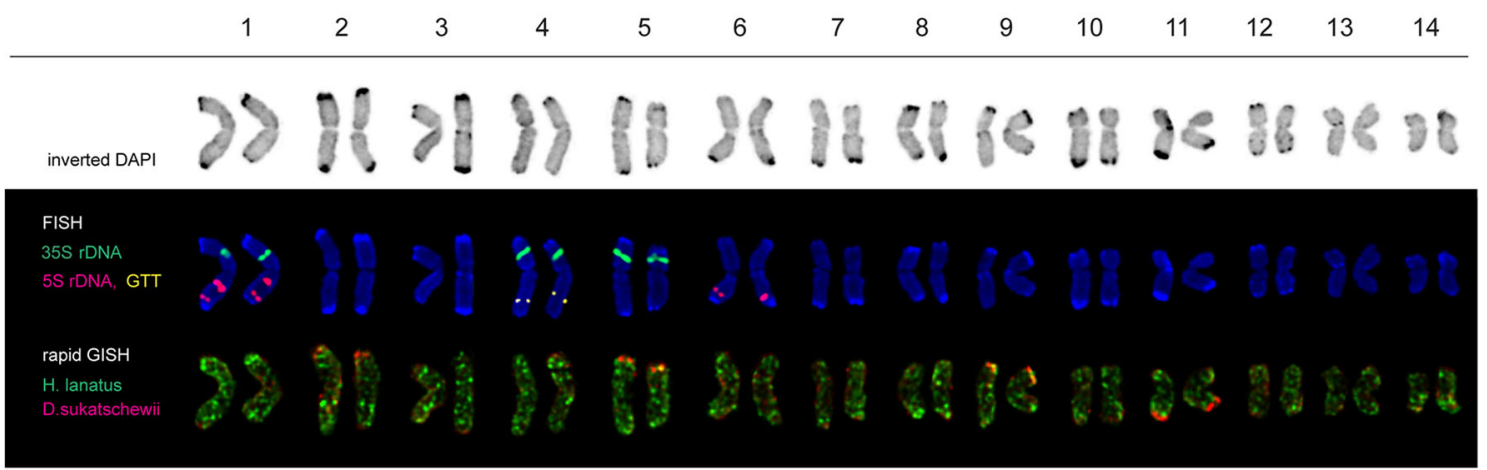

Deschampsia cespitosa

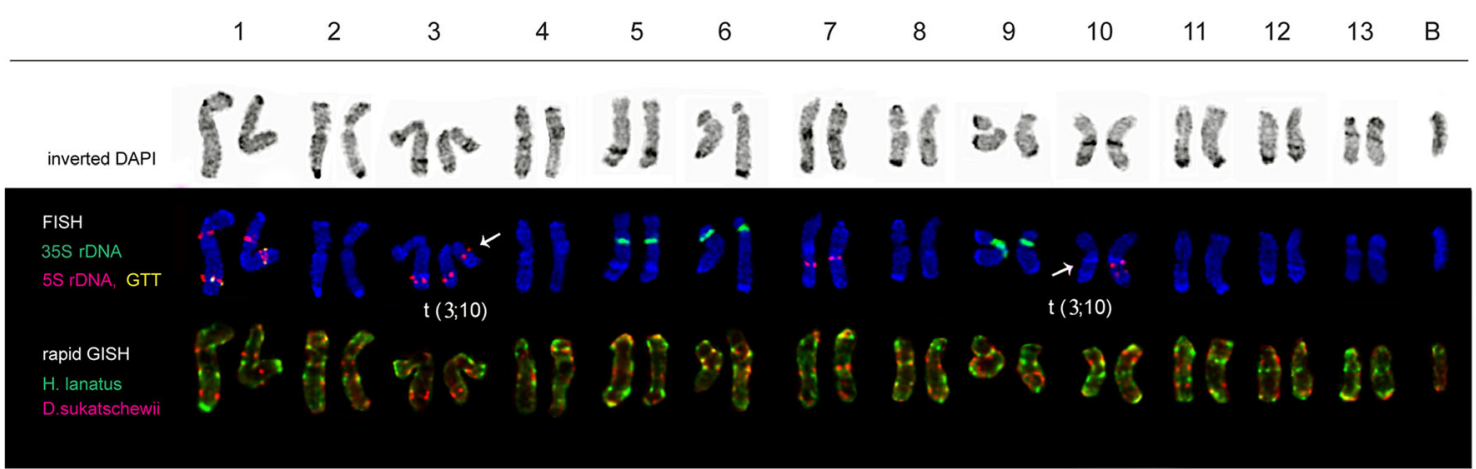

Deschampsia flexuosa

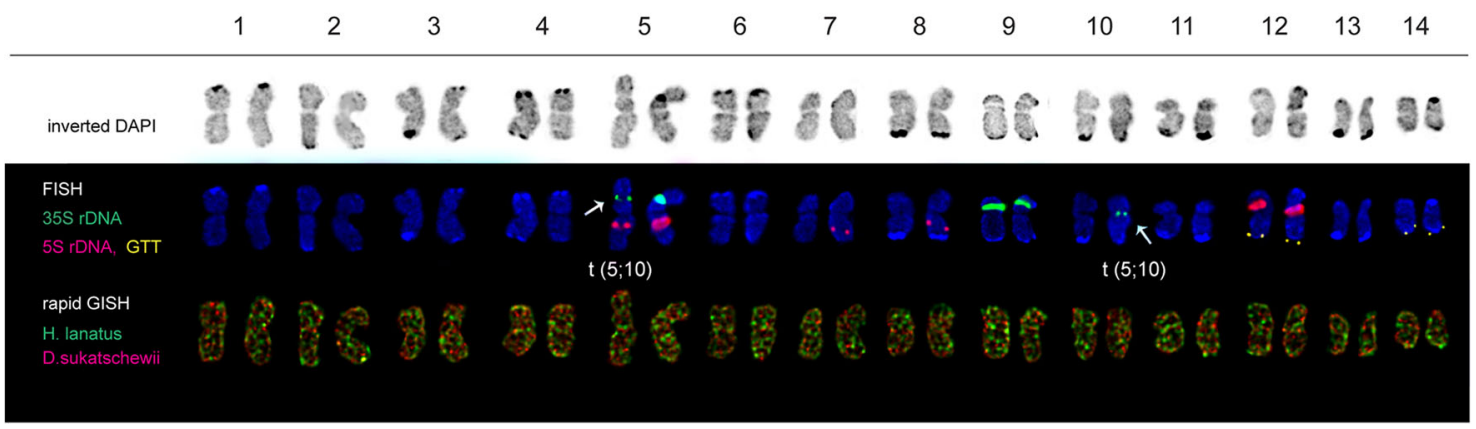

Fig. 5 (See legend on next page.) 
(See figure on previous page.)

Fig. 5 Karyotypes of A. arundinaceus, A. latifolia, D. cespitosa and D. flexuosa. Karyograms of the metaphase plates shown in Fig. 3 after DAPIbanding (inverted images), MC-FISH with the oligo-(GTT), $35 \mathrm{~S}$ and $5 \mathrm{~S}$ rDNA probes and also rapid MC-GISH with genomic DNAs of H. lanatus and D. sukatschewii. The correspondent probes and their pseudo-colours are specified in the left. Arrows point to chromosome rearrangements. B - B chromosome

pericentromeric regions of chromosome pairs 6 and 11 (Figs. 3a and 5).

In all studied karyotypes of the A. latifolia accession, MC-FISH analysis (performed for the first time) revealed large $35 \mathrm{~S}$ rDNA sites in the secondary constriction regions (short arms) of chromosome pairs 1, 4 and 5. Sites of $5 \mathrm{~S}$ rDNA were visualized in the interstitial and distal regions of the long arms of chromosome pair 1 and also in the distal regions of the long arms of chromosome pair 6. A small (GTT) $)_{9}$ site was detected in the distal regions of the long arms of chromosome pair 4 (Figs. 3c and 5).

In all examined karyotypes of the $D$. cespitosa accession, $35 \mathrm{~S}$ rDNA loci were located in the secondary constriction regions (short arms) of chromosome pairs 5, 6 and 9. 5S rDNA sites were observed on chromosome pair 1 (in the interstitial regions of both short and long arms), chromosome pair 3 (in the distal region of the long arms and in the proximal region of the short arm (hemizygous state)), chromosome pair 7 (in the proximal region of the long arms) and chromosome pair 10 (in the proximal and interstitial regions of the long arm (hemizygous state)). Small (GTT) ${ }_{9}$ sites were revealed in the interstitial region of the long arms of chromosome pair 1 (Figs. 3e and 5).

In all examined karyotypes of the D. flexuosa accession, $35 \mathrm{~S}$ rDNA loci were detected in the secondary constriction regions (short arms) of chromosome pairs 5 (a small site) and 9. Also, a small 35S rDNA locus was detected in the pericentromeric region of chromosome pair 10 (hemizygous state). Large 5S rDNA sites were detected in the interstitial region of the long arms of chromosome pair 5 and in the interstitial region of the short arms of chromosome pair 12. Besides, minor sites were revealed in the proximal regions of the long arms of chromosome pairs 7 and 8 (hemizygous state). Small (GTT) ${ }_{9}$ sites were detected in the subterminal regions of the long arms of chromosomes pairs 12 and 14 (Figs. 3g and 5).

\section{Chromosomal markers revealed by rapid MC-GISH}

A rapid MC-GISH procedure with total genomic DNAs of $H$. lanatus and D. sukatschewii as DNA probes was performed on chromosomes of $A$. aequalis, A. arundinaceus, A. latifolia, A. longiglumis, B. syzigachne, D. cespitosa and D. flexuosa. On chromosomes of $H$. lanatus, a rapid MC-GISH procedure was performed with the use of total genomic DNAs of D. flexuosa and D. sukatschewii as DNA probes.
Multiple clustered hybridization signals (rapid MCGISH markers) of $H$. lanatus were revealed in different positions on chromosomes of $A$. aequalis (Figs. $2 \mathrm{~b}$ and 4), A. arundinaceus (Figs. 3b and 5), A. latifolia (Figs. 3d and 5), B. syzigachne (Figs. 2f, h and 4) and D. cespitosa (Figs. 3f and 5). Dispersed and few clustered hybridization signals of $H$. lanatus were observed along the chromosomes of D. flexuosa (Figs. $3 \mathrm{~h}$ and 5). Few small clustered (coinciding with the localization of $35 \mathrm{~S}$ rDNA sites) and dispersed hybridization signals of $H$. lanatus were observed along the chromosomes of $A$. longiglumis (Figs. 2d and 4).

On chromosomes of $H$. lanatus, the rapid MC-GISH analysis revealed few small clustered and dispersed hybridization signals of $D$. flexuosa (Figs. $2 \mathrm{j}$ and 4 ).

Multiple clustered hybridization signals of $D$. sukatschewii were revealed in different positions on chromosomes of $A$. aequalis (Figs. $2 \mathrm{~b}$ and 4), A. arundinaceus (Figs. 3b and 5), B. syzigachne (Figs. 2f, h and 4) and D. cespitosa (Figs. 3f and 5). Besides, few small hybridization signals of $D$. sukatschewii were detected on chromosomes of H. lanatus (Figs. $2 \mathrm{j}$ and 4 ) and A. latifolia (Figs. 3d and 5). Dispersed and small clustered hybridization signals of $D$. sukatschewii were observed along the chromosomes of D. flexuosa (Figs. $3 \mathrm{~h}$ and 5). Dispersed signals of $D$. sukatschewii were observed along the chromosomes of A. longiglumis (Figs. 2d and 4).

\section{DAPI-banding analysis}

Chromosome staining with DAPI performed after FISH/GISH procedures revealed DAPI-banding patterns specific to the studied species accessions. Large (intense) DAPI-bands were observed in karyotypes of $A$. arundinaceus, $A$. latifolia, D. cespitosa, D. flexuosa and $H$. lanatus (mostly, in the pericentromeric and subterminal regions of chromosomes). Also, middlesized (interstitial, proximal and distal) bands were revealed on chromosomes of $A$. latifolia (chromosome pair 12), A. longiglumis (chromosome pairs 1, 2, 4 and 5), A. arundinaceus (chromosome pairs 1, 3, 4, 8, 10 and 14), D. cespitosa (chromosome pairs 1, 3, 5, 8 and 12), D. flexuosa (pair 12), and $H$. lanatus (chromosome pairs 1 and 4). On the other chromosomes of the studied accessions, small bands were detected. B chromosomes found in karyotypes of $D$. cespitosa and $H$. lanatus possessed distinct DAPIbands (Figs. 4 and 5). 


\section{Karyotype analysis}

Based on chromosomal morphology, DAPI-banding patterns, distribution of the oligo- $(\mathrm{GTT})_{9}, 35 \mathrm{~S}$ and $5 \mathrm{~S}$ rDNA probes as well as rapid GISH markers, chromosomes in karyotypes of the studied species were identified and the species karyograms were constructed (Figs. 4 and 5). The comparison of patterns of distribution of the examined molecular cytogenetic markers allowed us to reveal different chromosomal rearrangements in karyotypes of $B$. syzigachne, $D$. cespitosa and D. flexuosa (detailed in Figs. 4 and 5).

\section{Discussion}

Within the Aveneae/Poeae tribe complex, most grass species were shown to have a basic chromosome number $\mathrm{x}=$ 7, though other basic chromosome numbers have also been found (http://www.tropicos.org/project/ipcn). Besides, a natural polyploid series as well as variation in ploidy level were revealed [4, 15, 27, 39]. Polyploidy is widespread in grass species, and it considered to play an important role in the evolution of vascular plants [53, 54]. The speciation within the Aveneae/Poeae tribe complex has been accompanied with episodes of polyploidy and intergeneric hybridization between the representatives of this tribe (especially, having hybrid or/and rearranged genomes) resulted in appearance of allopolyploid species [55-58]. Polyploidization events often seem to be associated with increases in vigor followed by adaptation of newly formed polyploids to novel conditions [55-57], so polyploids are able to colonize larger geographic ranges and/or occur in more habitats than related diploids [54]. The genera Alopecurus, Arctagrostis, Beckmania, Deschampsia and Holcus comprise widespread polyploid species and/or polymorphic forms which are highly tolerant to stressful and/or variable environmental conditions $[6,8-10,55,59]$. The species $A$. aequalis, A. arundinaceus, A. latifolia, B. syzigachne, D. cespitosa, D. flexuosa, $D$. sukatschewii and $H$. lanatus are predominant grasses within the pastures of the Arctic and sub-Arctic regions $[6,10,11]$. However, only scattered data on their distribution in the vast territory of Eurasia is currently available. In the present study, we constructed the integrated schematic maps of their occurrence in the northern, central and eastern parts of Eurasia based on the currently available data $[2,6,45-52]$. These maps indicate the vast areas with multi-species occurrence and also the regions (predominantly in the Far North and the Far East) where only certain grass species are now distributed. In these regions, shortage in forage resources could be recovered through the introduction of the other Arctic grassland species with high levels of adaptation and seed productivity as well as developing new valuable cultivars with the use of promising wild morphotypes [11-13]. The grassland accessions examined in the present study were sampled in different parts of the sub-Arctic tundra (North West and Far East regions and also the highlands with sub-Arctic mountain climate) characterized by harsh climate, shallow soils, permafrost, high levels of UV radiation, low participations, strong winds, etc. In plants grown under various abiotic environmental stresses, different cytogenetic abnormalities (mixo-, aneu- and polyploidy, chromosome rearrangements, variability in chromosome number, distribution of rDNA loci and other DNA repeats, appearance of B chromosomes, etc.) are especially common [27, 37], and this karyotype diversity is considered to be related to the plasticity of plant genomes $[60,61]$. Despite the stressful natural environmental conditions, the cytogenetic analysis showed that the studied accessions presented normal diploid $(2 \mathrm{n}=2 \mathrm{x}=14, A$. aequalis, A. longiglumis, B. syzigachne and $H$. lanatus $)$ and tetraploid $(2 \mathrm{n}=4 \mathrm{x}=28, A$. arundinaceus, $A$. latifolia and $D$. flexuosa) karyotypes with the typical for cereals basic chromosome number $\mathrm{x}=7$, except for the paleopolyploid $D$. cespitosa having $2 n=26$ chromosomes. Our findings agreed with the cytological data reported earlier [36, 37, 62]. Particular, for D. cespitosa and some other Deschampsia species with $2 \mathrm{n}=26$, the analysis of meiotic chromosome behavior confirmed the basic number of chromosomes $(n=13)$ and also their diploid status [63]. This unusual for cereals chromosome number could be related to descending dysploidy, one of the most crucial routes of post-polyploid genome diploidization, which is described for several taxa of the Aveneae/ Poeae tribe complex [64].

In some cells of the studied $D$. cespitosa accession and also in one metaphase plate of the $H$. lanatus accession, we detected supernumerary small chromosomes with uncertain morphology and distinct DAPI bands. The frequency of those supernumerary chromosomes varied between individual plants as well as within root meristem of each plant. They could be referred to B chromosomes because Bs are known to be extra karyotype components which are generally smaller than the normal chromosomes (A chromosomes), often possess heterochrornatic segments and exhibit non-Mendelian inheritance [65]. B chromosomes have previously been revealed in various grass species including $D$. cespitosa $[37,62,65]$. Their appearance in a karyotype is associated with genome instability though functional role of Bs is still not fully understood $[65,66]$. In this study, the appearance of Bs in karyotypes of $D$. cespitosa and $H$. lanatus accessions could be related to environmental stress factors as a correlation between the presence of Bs in a karyotype and environmental conditions was described earlier [67, 68]. At the same time, the B chromosome detected in $H$. lanatus could be a fragment resulted from a break involving nearby chromosome 7 (which was smaller than its homo$\log$ ). Considering that Bs have not previously been described in $H$. lanatus, further molecular cytogenetic studies of different accessions of this species are required. 
Repetitive DNAs are major components of plant genomes which have high evolution rates and can lead to genome diversity [61, 69]. Knowledge of cytogenetic positions of specific repetitive sequences (chromosomal markers) provides information on genome structure differences which is important for analysis of the structural evolution of plant chromosomes [70]. Particularly, in karyotypes of vascular plants, DAPI staining, performed after FISH or GISH procedures, reveals AT-rich heterochromatin (which comprises highly repetitive DNA sequences) as strongly stained bands [71]. Clustered localization of highly repetitive DNA sequences (large distinct DAPI-bands) was observed on chromosomes of $A$. arundinaceus, $A$. latifolia, D. cespitosa, D. flexuosa and $H$. lanatus whereas in karyotypes of the other species, including A. longiglumis, we detected small DAPI-bands. The similar chromosomal distribution of constitutive heterochromatin was earlier described for different Avena species with the use of C-banding technique [30-32]. The comparison of the species distribution areas and their cytogenetic peculiarities indicated that karyotypes of two accessions from sub-Arctic mountain tundra ( $H$. lanatus and previously described D. sukatschewii [37]) possessed larger DAPI-bands (constitutive heterochromatin,) compared to the other accessions. This could be related to different pathways of plant genome reorganization (probably, for adaptation to the extreme environments) which involved highly repeated DNAs.

Physical mapping of ribosomal 35S and 5S DNA on chromosomes of diploid and polyploid plant species provides information on the structural evolution of the chromosomes carrying these sequences [28, 29, 72], whereas nucleotide similarity among diploid and polyploid rDNA copies reveals some of their phylogenetic and genomic relationships [73]. In this study, the comparative karyotypic analysis of the diploid and tetraploid accessions of Alopecurus ( $A$. aequalis and $A$. arundinaceus) revealed chromosomes with similar morphology and distribution patterns of $35 \mathrm{~S}$ rDNA, $5 \mathrm{~S}$ rDNA and DAPI-bands (e.g., chromosome 1 in A. aequalis and chromosome 2 in A. arundinaceus; chromosome 6 in A. aequalis and chromosome 10 in $A$. arundinaceus) which could be related to the allopolyploid origin of the $A$. arundinaceus genome. Interestingly, in both Alopecurus arundinaceus and Avena longiglumis (Al genome) karyotypes, we indicated one pair of chromosomes with the similar pattern of multiple rDNAs localization (large terminal 35S rDNA and distal 5S rDNA sites in the short arm and also interstitial 5S rDNA loci in the long arm). The similar chromosome pair was earlier described in diploid and polyploid Avena species with different types of the A genome [30-34], and it could be inherited from a common progenitor at a remote period. In karyotypes of $A$. latifolia, $H$. lanatus and $D$. flexuosa, we observed a large chromosome carrying a distal 35S rDNA site in the short arm and interstitial 5S rDNA loci in the long arm. The occurrence of multiple rDNA sites localized in specific chromosomes may have value in chromosome identification and elucidation of evolutionary relationships and also delineation of possible break point sites $[29,74]$.

Currently, microsatellite DNA sequences are widely used as FISH probes for cytogenetic studies as they are major components of many plant genomes [33, 34, 75]. Particularly, it has been recently determined that FISH with the oligo-GTT probe produces six constant signals located in the pericentromeric regions of three chromosome pairs of diploid A genome Avena species with minor interspecies differences in signal intensity [34]. These data indicate genomic variations among AA species and agree with the results of C-banding analysis [30-32] and Southern hybridization [76]. In the A. longiglumis accession studied here, FISH with the oligo$(\mathrm{GTT})_{9}$ probe revealed not only the six cluster signals mentioned above but also a number of minor signals which demonstrated intraspecific variability in chromosomal distribution of this microsatellite motif. Interestingly, on chromosomes of two species, Avena longiglumis and Alopecurus arundinaceus, clustered $(\mathrm{GTT})_{9}$ signals were detected in the pericentromeric regions. In karyotypes of the other studied species, only small distal or subterminal $(\mathrm{GTT})_{9}$ sites were observed. This agree with the molecular phylogenetic and cytogenetic data reported earlier $[5,34]$ and could be related to distant relationships between these species.

According to current molecular phylogenetic studies, the studied here grass species (except $A$. longiglumis) are included in chloroplast group 2 (Poaeae type) which is subdivided into two clades comprising genera 1) Avenella, Deschampsia, Holcus and 2) Alopecurus, Arctagrostis, Beckmannia [1]. In the present study, we used a rapid GISH approach to reveal common homologous DNA repeats in karyotypes of the studied species groups. We have previously reported that a rapid GISH procedure with genomic DNA of D. cespitosa revealed multiple large hybridization signals on chromosomes of $D$. sukatschewii (confirming their close relationships). We have also found that $D$. sukatschewii genome was rich in AT-heterochromatin [37]. Besides, the species from both Deschampsia and Holcus contain common DNA repeats CON1, CON2, COM1 and COM2 which are widespread in Poaceae [15]. In the rapid GISH assays performed in the present study, we used labelled genomic DNAs of $D$. sukatschewii and H. lanatus (chloroplast group 2) to reveal common DNA repeats on most studied species except $H$. lanatus. For $H$. lanatus chromosomes, we used genomic DNAs of D. sukatschewii and D. flexuosa as D. flexuosa differed karyotypically from $D$. sukatschewii and 
D. cespitosa [37]. The performed rapid MC-GISH analysis showed that species from both chloroplast groups possessed common DNA repeated sequences as clustered hybridization signals of genomic DNAs of both $H$. lanatus and D. sukatschewii were revealed in different positions on chromosomes of $A$. aequalis, $A$. arundinaceus, B. syzigachne, D. cespitosa and D. flexuosa. On chromosomes of $A$. latifolia, visual analysis revealed more hybridization signals of genomic DNA of $H$. lanatus (which therefore, indicated more genome similarities between these species) compared to genomic DNA of $D$. sukatschewii. At the same time, on chromosomes of $A$. longiglumis, which belongs to chloroplast group 1 (Aveneae type) [1, 5], we mostly observed dispersed hybridization signals of genomic DNAs of both $H$. lanatus and D. sukatschewii. Thus, our findings generally agree with the molecular phylogenetic data reported earlier $[1,5]$.

The genus Beckmannia comprises two perennial species, B. eruciformis and B. syzigachne. This genus has been subjected to several taxonomic revisions. Based on morphology, Beckmannia has been assigned to tribes Phalarideae, Chloriideae, Beckmanniinae and finally Aveneae (subtribe Alopecurinae) [77]. Until recently, molecular phylogenetic studies have not separated Beckmannia in a distinct lineage, tentatively leaving it within subtribe Alopecurinae [78-80] though support for potential separating Beckmannia and Alopecurus from each other has been provided [78]. Finally, however, Soreng et al. [1] has placed the genera Alopecurus and Beckmannia in two different subtribes (Alopecurinae and Beckmanniina). In support of these recent data, the molecular cytogenetic analysis performed in the present study did not reveal any karyotypic similarities between B. syzigachne and both diploid and tetraploid Alopecurus accessions. Nevertheless, further investigations of Beckmannia species based on different chromosomal and molecular markers are necessary to clarify the phylogenetic position of Beckmannia within the Aveneae/Poeae tribe.

Distribution patterns of the examined molecular cytogenetic markers in the studied here sub-Arctic accessions of $D$. cespitosa and D. flexuosa agreed with our previous results obtained for non-polar accessions [37]. Nevertheless, differences in number and size of some DAPI-bands as well as in localization of several chromosomal markers (mainly due to chromosomal rearrangements) were also observed. Molecular cytogenetic analysis of these species showed that their karyotypes differed significantly from each other. These results agreed with our previous findings indicating that $D$. flexuosa also had basic karyotypic differences with $D$. antarctica, D. danthonioides, D. elongata, D. sukatschewii and D. parvula [37]. According to the phylogenetic analyses inferred from nuclear ITS and plastid trnL sequence data, $D$. flexuosa is regarded a better suited to the genus Avenella [81]. However, rapid GISH assays with labelled genomic DNAs of both D. sukatschewii (in the present study) and D. cespitosa [37] detected clustered signals on chromosomes of $D$. flexuosa indicating the presence of common homologous highly repeated DNA sequences in their genomes.

It should be noticed that phylogenetic position of the genus Deschampsia within the family Poaceae is still controversial. According to Soreng et al. [1], Deschampsia, Holcus and Vahlodea were classified in the subtribe Holcinae which is not, however, monophyletic because Holcus and Vahlodea do not form a clade with Deschampsia in the plastid and nuclear ribosomal DNA trees [21, 22, 82]. In a parallel classification of grasses, Holcinae is treated as a synonym of Airinae [4]. Some recent authors render the genus Deschampsia paraphyletic [83] or consider that Deschampsia would be better treated in its own monotypic subtribe [23]. Our findings agreed with the last of these observations as the comparative molecular cytogenetic analysis of Deschampsia species and Holcus lanatus did not reveal similarities in distribution patterns of the studied chromosomal markers.

In karyotypes of B. syzigachne, D. cespitosa and D. flexuosa accessions sampled in different parts of the subArctic tundra (Far East and North West regions), chromosomal rearrangements were revealed. The presence of numerous chromosomal rearrangements in plant karyotypes is considered to be related to the genome plasticity $[60,61]$ and/or to speciation events [70, 84]. Accordingly, the process of genome evolution in these taxa could include chromosomal reorganization (chromosome interchanges, inversions, translocations) of the initial parental genomes.

Thus, the results of the present study provide unique information on distribution areas and cytogenomic structures of valuable Arctic and sub-Arctic pasture grass species from related genera of the Aveneae/Poeae tribe which revealed structural differences and also similar features in their karyotypes. The obtained results can be a basis for the further genetic and biotechnological studies.

\section{Conclusions}

The peculiarities of distribution patterns of the examined chromosomal markers and also presence of common homologous DNA repeats in karyotypes of the studies species allowed us to verify their relationships. The revealed karyotypic similarities between Alopecurus aequalis and Alopecurus arundinaceus indicated the allopolyploid origin of the A. arundinaceus genome. The karyotype of Beckmannia syzigachne differed greatly 
from the studied Alopecurus accessions in support of the recent molecular phylogenetic studies which have placed the genera Alopecurus and Beckmannia into different subtribes within the Poeae tribe. The comparative molecular cytogenetic analysis of Deschampsia species and Holcus lanatus confirmed the recent molecular phylogenetic data which suggested not be classified Deschampsia and Holcus in one subtribe. Our findings are important for further genetic and biotechnological studies and also plant breeding progress.

\section{Supplementary informations}

Supplementary information accompanies this paper at https://doi.org/10. 1186/s12863-019-0792-2.

Additional file 1: Table 1. Localization of $35 \mathrm{~S}$ rDNA, $5 \mathrm{~S}$ rDNA and $(\mathrm{GTT})$, sites on chromosomes of the studied diploid accessions

Additional file 2: Table 2. Localization of 35S rDNA, 5S rDNA and $(\mathrm{GTT})_{9}$ sites on chromosomes of the studied polyploid accessions

\section{Abbreviations}

MC-FISH: multicolour fluorescence in situ hybridization; rapid MC-GISH: rapid multicolour genomic in situ hybridization; rDNA: ribosomal DNA; sat DNA: satellite DNA

\section{Acknowledgements}

The authors acknowledge Dr. N.N. Kozlov and Dr. V.L. Korovina (Laboratory of genetic resources of fodder plants, FWRC of Forage Production and Agroecology, Lobnya, Moscow region, RF) for providing us valuable plant materials.

\section{Authors' contribution}

The present study was conceived and designed by AVA, OVM and SAZ. AVA, OVM, SAZ, OYY, TES and LG carried out the experiments. AVA, OVM, AVR, SAZ, OYY, TES and LG analyzed the obtained data. AVR, EOP and IGL provided plant materials. All authors participated in preparing and writing the manuscript. AVA, OVM, SAZ and AVR performed the analysis with constructive discussions. All authors have read and approved the final manuscript. AVA and SAZ contributed equally to this work.

\section{Funding}

This work was supported by the Russian Foundation of Basic Research (KOMFI project no. 17-00-00340 (17-00-00336 OVM, 17-00-00337 AVR and 17-00-00338 IGL). The funders had no role in study design, data collection and analysis, decision to publish, or preparation of the manuscript.

\section{Availability of data and materials}

All data generated or analysed during this study are included in this published article and its supplementary information files.

\section{Ethics approval and consent to participate}

This study including the plant sample collection and experimental research conducted on these materials was according to the federal law on environmental protection approved by the Council of the Russian Federation.

\section{Consent for publication}

Not applicable.

\section{Competing interests}

The authors declare that they have no competing interests.

\section{Author details}

${ }^{1}$ Engelhardt Institute of Molecular Biology, Russian Academy of Sciences, Moscow, Russian Federation. ${ }^{2}$ Komarov Botanical Institute, Russian Academy of Sciences, St. Petersburg, Russian Federation. ${ }^{3}$ Federal Research Center N.I.
Vavilov All-Russian Institute of Plant Genetic Resources (VIR), Russian Academy of Sciences, St. Petersburg, Russian Federation.

Received: 4 July 2019 Accepted: 22 November 2019

Published online: 04 December 2019

\section{References}

1. Soreng RJ, Peterson PM, Romaschenko K, Davidse G, Zuloaga FO, Judziewicz EJ, et al. A worldwide phylogenetic classification of the Poaceae (Gramineae). J Syst Evol. 2015;53:117-37. https://doi.org/10.1111/jse.12150.

2. Tzvelev NN. Zlaki SSSR. Leningrad: Nauka Publishers; 1976. [English translation: Grasses of the Soviet Union, 1983, vol. 1 and 2. Oxonian Press Pvt. Ltd., New Delhi.]

3. Rasane P, Jha A, Sabikhi L, Kumar A, Unnikrishnan VS. Nutritional advantages of oats and opportunities for its processing as value added foods. J Food Sci Technol. 2015;52:662-75. https://doi.org/10.1007/s13197-013-1072-1.

4. Kellogg EA. Flowering plants. Monocots: Poaceae. In: Kubitzki K, editor. The families and genera of vascular plants, vol. XIII. Cham: Springer; 2015. https://doi.org/10.1007/978-3-319-15332-2.

5. Soreng RJ, Peterson PM, Romaschenko K, Davidse G, Teisher JK, Clark LG, Barber P, Gillespie LJ, Zuloaga FO. A worldwide phylogenetic classification of the Poaceae (Gramineae) II: an update and a comparison of two 2015 classifications. J Syst Evol. 2017;55:259-90. https://doi.org/10.1111/jse.12262.

6. Tzvelev NN. Arctic flora of the USSR. V 2. Moscow-Leningrad: Nauka; 1964

7. Hulten E. Flora of Alaska and neighboring territories. Stanford: Stanford University Press; 1968.

8. Alberdi M, Bravo LA, Gutiérrez A, Gidekel M, Corcuera LJ. Ecophysiology of Antarctic vascular plants. Physiol Plant. 2002;115:479-86.

9. Thompson JD, Turkington R. The biology of Canadian weeds. 82. Holcus lanatus L. CJPS. 1988;68:131-47.

10. Kazmin VD, Kholod SS, Rozenfeld SB, Abaturov BD. Current state of forage resources and feeding of reindeer (Rangifer tarandus) and musk oxen (Ovibos moschatus) in the arctic tundras of Wrangel Island. Biol Bull. 2011;38: 47-753

11. Ivanova OG. Elements of agro-technology for seed production of subpolar and polar ecotypes perennial cereal grasses. Int Res J. 2016;10(52):144-6. https://doi.org/10.18454/IRJ.2016.52.138.

12. Ivanova OG. Agrobiological parameters of selection samples the offspring of aboriginal ecotype Arctagrostis latifolia. Int Res J. 2016;10(52):147-9. https:// doi.org/10.18454/IRJ.2016.52.139.

13. John UP, Spangenberg G. Xenogenomics: genomic bioprospecting in indigenous and exotic plants through EST discovery, cDNA microarraybased expression profiling and functional genomics. Comp Funct Genomics. 2005:6:230-5. https://doi.org/10.1002/cfg.475.

14. Byun MY, Lee J, Cui LH, Kang Y, Oh TK, Park H, et al. Constitutive expression of DaCBF7, an Antarctic vascular plant Deschampsia antarctica CBF homolog, resulted in improved cold tolerance in transgenic rice plants. Plant Sci. 2015;236:61-74. https://doi.org/10.1016/j.plantsci.2015.03.020.

15. Röser M, Winterfeld G, Döring E, Schneider J. Chromosome evolution in grass tribes Aveneae/Poeae (Poaceae): insights from karyotype structure and molecular phylogeny. Schlechtendalia. 2014;28:1-21.

16. Nikoloudakis N, Skaracis G, Katsiotis A. Evolutionary insights inferred by molecular analysis of the ITS1-5.8S-ITS2 and IGS Avena sp. sequences. Mol Phylogenet Evol. 2008;46:102-15. https://doi.org/10.1016/j.ympev. 2007.10.007.

17. Fu YB. Oat evolution revealed in the maternal lineages of 25 Avena species. Sci Rep. 2018:8:4252. https://doi.org/10.1038/s41598-018-22478-4.

18. He X, Bjørnstad $\AA$. Diversity of North European oat analyzed by SSR, AFLP and DArT markers. Theor Appl Genet. 2012;125:57-70. https://doi.org/10. 1007/s00122-012-1816-8.

19. Paczos-Grzeda E, Bednarek PT. Comparative analysis of hexaploid Avena species using REMAP and ISSR methods. Turk J Bot. 2014;38:1103-11. https://doi.org/10.3906/bot-1403-10.

20. Rodrigues J, Viegas W, Silva M. 45S rDNA external transcribed spacer organization reveals new phylogenetic relationships in Avena genus. PLoS One. 2017;12(4):e0176170. https://doi.org/10.1371/journal.pone.0176170.

21. Quintanar A, Castroviejo S, Catalán P. Phylogeny of the tribe Aveneae (Pooideae, Poaceae) inferred from plastid trnT-F and nuclear ITS sequences. Am J Bot. 2007;94:1554-69. https://doi.org/10.3732/ajb.94.9.1554.

22. Saarela JM, Liu Q, Peterson PM, Soreng RJ, Paszko B. Phylogenetics of the grass 'Aveneae-type plastid DNA clade' (Poaceae: Pooideae, Poeae) 
based on plastid and nuclear ribosomal DNA sequence data. In: Seberg O, Petersen G, Barfod AS, Davis Jl, editors. Diversity, phylogeny, and evolution in the monocotyledons. Aarhus: Aarhus University Press; 2010. p. 557-87.

23. Saarela JM, Bull RD, Paradis MJ, Ebata SN, Peterson PM, Soreng RJ, et al. Molecular phylogenetics of cool-season grasses in the subtribes Agrostidinae, Anthoxanthinae, Aveninae, Brizinae, Calothecinae, Koeleriinae and Phalaridinae (Poaceae, Pooideae, Poeae, Poeae chloroplast group 1). PhytoKeys. 2017;87:1-139. https://doi.org/10.3897/phytokeys.87.12774.

24. Soreng RJ, Davis Jl. Phylogenetic structure in Poaceae subfamily Pooideae as inferred from molecular and morphological characters: misclassification versus reticulation. In: Jacobs SWL, Everett J, editors. Grasses: systematics and evolution. Collingwood: CSIRO Publishing; 2000. p. 61-74.

25. Madlung A, Comal $L$. The effect of stress on genome regulation and structure. Ann Bot. 2004;94:481-95.

26. Chinnusamy V, Zhu JK. Epigenetic regulation of stress response in plants. Curr Opin Plant Biol. 2009;12:133-9. https://doi.org/10.1016/j.pbi.2008.12.006.

27. Amosova AV, Bolsheva NL, Samatadze TE, Twardovska MO, Zoshchuk SA, Andreev IO, et al. Molecular cytogenetic analysis of Deschampsia antarctica Desv. (Poaceae), Maritime Antarctic. PLoS One. 2015;10(9):e0138878. https:// doi.org/10.1371/journal.pone.0138878.

28. Tomas D, Rodrigues J, Varela A, Veloso MM, Viegas W, Silva M. Use of repetitive sequences for molecular and cytogenetic characterization of Avena species from Portugal. Int J Mol Sci. 2016;7:203. https://doi.org/10. 3390/ijms17020203.

29. Garcia S, Kovařik A, Leitch AR, Garnatje T. Cytogenetic features of rRNA genes across land plants: analysis of the plant rDNA database. Plant J. 2017; 89:1020-30. https://doi.org/10.1111/tpj.13442.

30. Shelukhina OY, Badaeva ED, Brezhneva TA, Loskutov IG, Pukhal'skii VA. Comparative analysis of diploid species of Avena l. using cytogenetic and biochemical markers: Avena canariensis Baum et Fedak and A. longiglumis Dur. Russ J Genet. 2008;44:798-806.

31. Badaeva ED, Shelukhina OY, Goryunova SV, Loskutov IG, Pukhalskiy VA. Phylogenetic relationships of tetraploid AB-genome Avena species evaluated by means of cytogenetic (C-banding and FISH) and RAPD analyses. J Bot. 2010;2010:1-13. https://doi.org/10.1155/2010/742307.

32. Badaeva ED, Shelukhina OY, Dedkova OS, Loskutov IG, Pukhalskyi VA. Comparative cytogenetic analysis of hexaploid Avena L. Species Russ J Genet. 2011;47:691-702. https://doi.org/10.1134/s1022795411060068.

33. Fominaya A, Loarce $Y$, Montes A, Ferrer E. Chromosomal distribution patterns of the $(A C)_{10}$ microsatellite and other repetitive sequences, and their use in chromosome rearrangement analysis of species of the genus Avena. Genome. 2017;60:216-27. https://doi.org/10.1139/gen-2016-0146.

34. Luo X, Tinker NA, Zhou Y, Liu J, Wan W, Chen L. Chromosomal distributions of oligo-Am1 and (TTG) 6 trinucleotide and their utilization in genome association analysis of sixteen Avena species. Genet Resour Crop Evol. 2018; 65:1625-35. https://doi.org/10.1007/s10722-018-0639-0.

35. Loskutov IG. On evolutionary pathways of Avena species. Genet Resour Crop Evol. 2008;55:211-20. https://doi.org/10.1007/s10722-007-9229-2.

36. Winterfeld G. Molekular-cytogenetische Untersuchungen an Hafergräsern (Aveneae) und anderen Poaceae. Stapfia. 2006:86:1-170.

37. Amosova AV, Bolsheva NL, Zoshchuk SA, Twardovska MO, Yurkevich OY, Andreev IO, et al. Comparative molecular cytogenetic characterization of seven Deschampsia (Poaceae) species. PLoS One. 2017;12(4):e0175760. https://doi.org/10.1371/journal.pone.0175760.

38. Index to Plant Chromosome Numbers (IPCN). Tropicos.org. Missouri Botanical Garden. http://www.tropicos.org/Project/IPCN

39. Sieber V, Muray BG. The cytology of the genus Alopecurus (Gramineae). Bot J Linn Soc. 1979;79:343-55. https://doi.org/10.1111/j.1095-8339.1979.tb01822.x.

40. Loskutov I, Rines HW. Avena. In: Kole C, editor. Wild crop relatives: genomic and breeding resources: cereals. New York: Springer; 2011. p. 109-83.

41. Gerlach WL, Bedbrook JR. Cloning and characterization of ribosomal RNA genes from wheat and barley. Nucleic Acids Res. 1979;7:1869-85.

42. Gerlach WL, Dyer TA. Sequence organization of the repeating units in the nucleus of wheat which contain 5S rRNA genes. Nucleic Acids Res. 1980;8: 4851-5.

43. Muravenko OV, Yurkevich OY, Bolsheva NL, Samatadze TE, Nosova IV, Zelenina DA, et al. Comparison of genomes of eight species of sections Linum and Adenolinum from the genus Linum based on chromosome banding, molecular markers and RAPD analysis. Genetica. 2009;135:245-55. https://doi.org/10.1007/s10709-008-9273-7.
44. Doyle JJ, Doyle JL. A rapid DNA isolation procedure for small quantities of fresh leaf tissue. Phytochem Bull. 1987;19:11-5.

45. Flora of the USSR. Vol 2. Gramineae (Poaceae). In: Komarov VL, editor. Leningrad: USSR Academy of Sciences Publisher; 1934.

46. Flora of Northeast of the European part of the USSR, Vol. 1. In: Tzvelev NN, editor. Leningrad: Nauka; 1974.

47. Harkevich SS. Wild fodder grass of Far East. Moscow: Nauka; 1982.

48. Ramenskaya IL. Analysis of flora Murmansk' district and Karelia. Leningrad: Nauka; 1983.

49. Khokhryakov AP. Flora of the Magadan region. Moscow: Nauka Publishers; 1985.

50. Hulten E, Fries M. Atlas of north European vascular plants, north of the tropic of cancer. Konigstein: Koeltz; 1986.

51. Flora of the Siberia. Vol. 2. Poaceae (Graminea). In: Malyshev LI, Peshkova GA, editors. Novosibirsk: Nauka; 1990.

52. Kravchenko AV. A compendium of Karelian flora (vascular plants). Karelian Research Centre RAS: Petrozavodsk; 2007.

53. Levy AA, Feldman M. The impact of polyploidy on grass genome evolution. Plant Physiol. 2002;130:587-1593. https://doi.org/10.1104/pp.015727.

54. Ramsey J, Ramsey TS. Ecological studies of polyploidy in the 100 years following its discovery. Phil Trans R Soc B. 2014;369:20130352. https://doi. org/10.1098/rstb.2013.0352.

55. Brochmann C, Brysting AK, Alsos IG, Borgen L, Grundt HH, Scheen AC, et al. Polyploidy in arctic plants. Biol J Linn Soc. 2004;82:521-36.

56. Soltis $\mathrm{P}$, Soltis D. The role of hybridization in plant speciation. Ann Rev Plant Biol. 2009:60:561-88. https://doi.org/10.1146/annurev.arplant.043008.092039.

57. Sattler MC, Carvalho CR, Clarindo WR. The polyploidy and its key role in plant breeding. Planta. 2016;243:281-96. https:/doi.org/10.1007/s00425-015-2450-x.

58. Rodionov AV, Amosova AV, Belyakov EA, Zhurbenko PM, Mikhailova YV, Punina EO, Shneyer VS, Loskutov IG, Muravenko OV. Genetic consequences of interspecific hybridization, its role in speciation and phenotypic diversity of plants. Russ J Genet. 2019;55:278-94. https://doi.org/10.1134/ S0016675819030159.

59. A K, Lewińska K, Gałka B. Arsenic extractability and uptake by velvetgrass Holcus lanatus and ryegrass Lolium perenne in variously treated soils polluted by tailing spills. J Hazard Mater. 2013;262:1014-21. https://doi.org/ 10.1016/j.jhazmat.2012.09.008.

60. Nevo E. Genomic diversity in nature and domestication. In: Henry RJ, editor. Plant diversity and evolution: genotypic and phenotypic variation in higher plants. Wallingford: CABI Publishing; 2005. p. 287-315.

61. Weber N, Halpin C, Hannah LC, Jez JM, Kough J, Parrott W. Crop genome plasticity and its relevance to food and feed safety of genetically engineered breeding stacks. Plant Physiol. 2012;160(4):1842-53. https://doi. org/10.1104/pp.112.204271

62. Cardone S, Sawatani P, Rush P, Garcia A, Poggio L, Schrauf G. Karyological studies in Deschampsia antarctica Desv. (Poaceae). Polar Biol. 2009;32:42733. https://doi.org/10.1007/s00300-008-0535-8.

63. Rothera SL, Davy AJ. Polyploidy and habitat differentiation in Deschampsia cespitosa. New Phytol. 1986;102:449-67. https://doi.org/10.1111/j.1469-8137. 1986.tb00822.x.

64. Pimentel M, Escudero M, Sahuquillo E, Minaya MA, Catalán P. Are diversification rates and chromosome evolution in the temperate grasses (Pooideae) associated with major environmental changes in the OligoceneMiocene? PeerJ. 2017;5:e3815. https://doi.org/10.7717/peerj.3815.

65. Houben A. B chromosomes - a matter of chromosome drive. Front Plant Sci. 2017:8:210. https://doi.org/10.3389/fpls.2017.00210.

66. Houben A, Banaei-Moghaddam AM, Klemme S. Biology and evolution of B chromosomes. In: Greilhuber J, Dolezel J, Wendel JF, editors. Plant genome diversity. Vienna: Springer; 2013. p. 149-65. https://doi.org/10.1007/978-37091-1160-4_10.

67. Camacho JP, Sharbel TF, Beukeboom LW. B chromosome evolution. Phil Trans R Soc B. 2000;355:163-78. https://doi.org/10.1098/rstb.2000.0556.

68. Pereira HS, Delgado M, Viegas W, Rato JM, Barão A, Caperta AD. Rye (Secale cereale) supernumerary (B) chromosomes associated with heat tolerance during early stages of male sporogenesis. Ann Bot. 2017;119:325-37. https:// doi.org/10.1093/aob/mcw206.

69. Mehrotra S, Goyal V. Repetitive sequences in plant nuclear DNA: types, distribution, evolution and function. Genomics Proteomics Bioinformatics. 2014;12:164-71. https://doi.org/10.1016/j.gpb.2014.07.003.

70. Flavell RB, O'Dell M, Hutchinson J. Nucleotide sequence organization in plant chromosomes and evidence for sequence translocation during evolution. Cold Spring Harb Symp Quant Biol. 1981;45:501-8. 
71. Barros e Silva AE, Guerra M. The meaning of DAPI bands observed after Cbanding and FISH procedures. Biotech Histochem. 2010;85:115-25. https:// doi.org/10.1080/10520290903149596.

72. Linares C, González J, Ferrer E, Fominaya A. The use of double-fluorescence in situ hybridization to physically map the positions of $5 S$ rDNA genes in relation to the chromosomal location of 18S-5.8S-26S rDNA and a C genome-specific DNA sequence in the genus Avena. Genome. 1996;39:535-42.

73. Peng YY, Baum BR, Ren $C Z$, Jiang $Q T$, Chen GY, Zheng YL, et al. The evolution pattern of rDNA ITS in Avena and phylogenetic relationship of the Avena species (Poaceae: Aveneae). Hereditas. 2010;147:183-204. https://doi. org/10.1111/j.1601-5223.2010.02172.x.

74. Lavania UC, Basu S, Srivastava S, Mukai Y, Lavania S. In situ chromosomal localization of rDNA sites in "safed musli" Chlorophytum Ker-Gawl and their physical measurement by fiber FISH. J Hered. 2005;96:155-60. https://doi. org/10.1093/jhered/esi018.

75. Badaeva ED, Amosova AV, Goncharov NP, Macas J, Ruban AS, Grechishnikova IV, et al. A set of cytogenetic markers allows the precise identification of all A-genome chromosomes in diploid and polyploid wheat. Cytogenet Genome Res. 2015;146:71-9. https://doi.org/10.1159/ 000433458.

76. Irigoyen $\mathrm{ML}$, Loarce $\mathrm{Y}$, Linares $\mathrm{C}$, Ferrer $\mathrm{E}$, Leggett $\mathrm{M}$, Fominaya $\mathrm{A}$. Discrimination of the closely related $A$ and $B$ genomes in $A A B B$ tetraploid species of Avena. Theor Appl Genet. 2001;103:1160-6. https://doi.org/10. 1007/s001220100723.

77. Clayton WD, Renvoiz SA. Genera Graminum: grasses of the world. London: Her Majesty's Stationery Office; 1986.

78. Gillespie L, Soreng RJ, Bull RD, Jacobs SWL, Refulio-Rodriguez NF. Phylogenetic relationships in subtribe Poinae (Poaceae, Poeae) based on nuclear ITS and plastid trnT-trnL-trnF sequences. Botany. 2008;86:938-67. https://doi.org/10.1139/B08-076.

79. Gillespie L, Soreng RJ, Paradis M, Bull RD. Phylogeny and reticulation in subtribe Poinae and related subtribes (Poaceae) based on nrlTS, ETS and trnTLF data. Botany. 2008:86:938-67. https://doi.org/10.1139/B08-07.

80. Xu C, Qu C, Yu W, Zhang X, Li F. Phylogenetic origin of Beckmannia (Poaceae) inferred from molecular evidence. J Syst Evol. 2009:47:305-10.

81. Chiapella J. A molecular phylogenetic study of Deschampsia (Poaceae: Aveneae) inferred from nuclear ITS and plastid trnL sequence data: support for the recognition of Avenella and Vahlodea. Taxon. 2007;56:55-64.

82. Persson NL, Rydin C. Phylogenetic relationships of the 'Briza complex' to other members of the subfamily Pooideae (Poaceae). Plant Ecol Evol. 2016; 149:216-27. https://doi.org/10.5091/plecevo.2016.1194.

83. Chiapella J, Zuloaga FO. A revision of Deschampsia, Avenella, and Vahlodea (Poaceae, Poeae, Airinae) in South America. Ann Missouri Bot Gard. 2010;97: 141-62. https://doi.org/10.3417/2008115.

84. Raskina O, Barber JC, Nevo E, Belyayev A. repetitive DNA and chromosomal rearrangements: speciation-related events in plant genomes. Cytogenet Genome Res. 2008;120:351-7. https://doi.org/10.1159/000121084.

\section{Publisher's Note}

Springer Nature remains neutral with regard to jurisdictional claims in published maps and institutional affiliations.

\section{Ready to submit your research? Choose BMC and benefit from:}

- fast, convenient online submission

- thorough peer review by experienced researchers in your field

- rapid publication on acceptance

- support for research data, including large and complex data types

- gold Open Access which fosters wider collaboration and increased citations

- maximum visibility for your research: over $100 \mathrm{M}$ website views per year

At $\mathrm{BMC}$, research is always in progress.

Learn more biomedcentral.com/submissions 